\title{
Floricultural Quality Traits and Probing Mechanisms of Silicon Mediated Disease Resistance of Dendrobium
}

\section{Darshani Weerahewa*}

Department of Botany, The Open University of Sri Lanka

\begin{abstract}
Dendrobium sp. (Orchidaceae) is the most 'in demand' cut flower in the export and local market due to its vivid and variable flower colouration. However, the production of quality flowers is a major obstacle and is the main factor contributing to the export potential of the cut flower industry in Sri Lanka. This research was focused on improving floricultural quality, growth and enhancing disease resistance of Dendrobium by preharvest application of soluble silicon.
\end{abstract}

The experiments were conducted in a mesh house at $50 \%$ shade and were designed as a Completely Randomized Design (CRD). Each treatment or control plant consisted of 12 replicates and the experiment was repeated twice. The orchid plants were potted in clay pots and provided with $100 \mathrm{mg} / \mathrm{L}$ of sodium silicate at weekly intervals, showed significantly higher shoot length, leaf length and number of leaves compared to silicon provided bi-weekly or in the controls. Plants grown in a newly designed aeroponic system and treated with $100 \mathrm{mg} / \mathrm{L}$ silicon weekly showed significantly improved floricultural quality traits: a higher number of flowers per spike and higher spike length, higher spike thickness and higher flower length and diameter compared to the plants treated at $50 \mathrm{mg} / \mathrm{L}$ or untreated plants.

Natural disease development of leaf spot disease was significantly lower in plants treated with silicon as compared to the control. The average leaf thickness, cuticle thickness and total soluble phenol 
content were significantly higher in plants treated with silicon. These results indicate that mechanical barriers in the form of cuticle thickness and leaf thickness contribute towards the reduction of disease development. Increased levels of total soluble phenols in leaves of silicon treated plants may be also contributing biochemically towards warding off disease.

Keywords: Dendrobium, floricultural quality, silicon, phenol, cuticle thickness

\section{Introduction}

Floriculture is a profitable industry in Sri Lanka earning about 25\% of the annual export income. Dendrobium sp. (Orchidaceae) is the most 'in demand' cut flower in the export and local market due to its vivid and variable flower colouration. However, the production of quality flowers is a major obstacle to the export potential of cut flowers in Sri Lanka. The control of Dendrobium floral diseases is currently achieved by application of systemic fungicides. However, the prolonged use of fungicides causes development of tolerant strains to fungicides. Further, the existing chemical strategies to combat these diseases are very expensive, environmentally unsound and hazadous. Hence, this research focused on developing disease control measures through induction of natural disease resistance mechanisms. Natural disease resistance in Dendrobium spp was induced or enhanced using abiotic elicitors, such as silicon in order to suppress development of disease during the preharvest phase and improve the floricultural quality of flowers.

No reseach so far has been carried out to improve the floricultural quality and reduce diseases of Dendrobium plant/flower using nonhazardous methods. The potential benefits of silicon nutrition in plants are extensively studied worldwide. Some of these include: the enhancement of growth and yield (Ma, 2004; Datnoff et al., 2001), reduced cuticle transpiration and increased tolerance to lodging (Ma $\&$ Yamaji, 2006). It was observed that in rice, silicon stimulates erect growth enhancing light capturing ability and increases photosynthetic rates (Ma et al., 1989). Other benefits of silicon in abiotic stress environments can be listed as, reduced mineral toxicity, and enhanced drought and frost tolerance (Ma, 2004). When 
considering biotic stresses, a number of studies showed that silicon alleviates pest and disease damages and powdery mildew in wheat (Belanger et al., 2003), cucumber (Menzies et al., 1992), anthracnose in capsicum (Jayawardena et al., 2014a; Jayawardena et al., 2014b ; Jayawardana et al., 2015 \& Jayawardana et al., 2016), and anthracnose in tomato (Huang et al., 2011 ; Weerahewa \& David, 2015), Phythium root rot in cucumber (Cherif \& Belanger, 1992) and Fusarium root rot (Safari et al., 2012).

Defensive mechanisms enhanced by silicon are explained by various methods. Silicon has been proven to be effective in controlling various diseases and pests in many important crops via stimulating the plants forming a mechanical barrier against the infection at the infection site or producing antimicrobial compounds. Silicon deposited on the tissue surface acts as a physical barrier preventing physical penetration and/or making the plant cells less susceptible to enzymatic degradation by fungal pathogens. This mechanism is supported by the positive correlation between the Si content and the degree of suppression of diseases and pests. Resistance against penetration may be due to accumulation and polymerization of $\mathrm{Si}$ at sites of penetration (Kunoh \& Ishizaki, 1975) and strengthening of cell walls (Kim et al., 2002). Accumulation of Si on stems at infected sites of powdery mildew of Arabidopsis, made the plant more resistant against the pathogen, Erysiphe cichoracearum (Blaich \& Grundhöfer, 1998). Further, Si accumulated and deposited beneath the cuticle forms a Si-cuticle double layer acting as a mechanical barrier against infections (Samuel et al., 1991). Application of liquid potassium silicate suppressed conidial germination and appressorial formation of Sphaerotheca aphanis var. Aphanis which causes powdery mildew on strawberry (Kanto et al., 2006).

Rodrigues et al. (2003) revealed that $\mathrm{Si}$ enhanced the accumulation of diterpenoid Phytoalexins in rice at infected sites, which controlled blast disease caused by Magnaporthe grisea. Defense response was induced by soluable $\mathrm{Si}$ in cucumber roots infected by Pythium spp. due to stimulation of chitinase activity and rapid activation of peroxidases and polyphenol oxidases. Glycosidically bound phenolics extracted from Si-treated plants displayed a strong fungistatic activity when subjected to acid or, $\beta$-glucosidase hydrolysis (Carver et al., 1998). 
Recent findings indicate that silicon supplimentation improved the quality of Gerbera (Savvas et al., 2002 ), Roses (Ehret et al., 2005), Helianthus (Kamenidou et al., 2008), Sunflower and Zinnia (Kamenidou et al., 2008, 2009).

The present research was carried out to investigate the effects of silicon supplementation and application time on growth parameters (stem length, leaf length and number of leaves), and some floricultural quality traits in flowers (days for anthesis, number of flowers per spike, flower size, length and diameter of spike) of Dendrobium orchids. The mechanism underlying the silicon on diseases was investigated by measuring the thickness of the cuticle and levels of phenols in the silicon treated leaves.

\section{Materials and Methods}

\section{Plant Material}

Healthy, mature, tissue cultured, Dendrobium plants (12 month old, cv. Ckai brownderby-TDC-23, and 18 month old cv. Sonia) bought from the orchid nursery at the Department of Agriculture, National Botanical gardens, Peradeniya were used in the experiments.

Plants were kept in a mesh house at the Open University of Sri Lanka, Nawala. The mesh house environment provided the required 50\% shade by shade nets, and misting of water was done to maintain the required temperature $\left(28{ }^{\circ} \mathrm{C}\right)$ and high humidity $(80 \% \mathrm{RH})$ levels. The recommended NPK (20: 20: 20) levels of fertilizer (01 g/ $1 \mathrm{~L}$ water) was provided bi-weekly.

\section{Preharvest Application of Silicon}

\section{Application of silicon to potted orchid plants}

Three sets of Dendrobium plants of $c v$. Ckai brownderby, each containing 12 plants, in clay pots containing charcoal and tile pieces were used for this study.

Silicon suppliments were provided by applying sodium silicate (Sigma Aldrich Inc. USA) as a spray ( $5 \mathrm{~mL}$ of solution per plant as a fine mist) using a $1 \mathrm{~L}$ spraying bottle. One set of 12 plants were treated with sodium silicate $(100 \mathrm{mg} / \mathrm{L})$ at weekly intervals. The second set of 12 
plants with the same concentration of sodium silicate $(100 \mathrm{mg} / \mathrm{L})$ was applied bi-weekly. The third set of 12 plants was sprayed with only water and maintained as the control.

\section{Application of Silicon to Plants Grown as an Aeroponics System}

Eighteen (18) month old Dendrobium sp. (cv.Sonia) was transplanted in an aeroponics system as illustrated in Fig. 1. Eight plants were put into net pots incorporating charcoal pieces. Fertilizer (Standard NPK (20: 20:20) was sprayed as a mist into boxes every day for a period of 5 min thrice daily using pipe systems and electric pump (Fig. 1). Three boxes were connected to the nutrient tank containing the above fertilizer and the excess solution was recycled. The diagramic view of the one box connected to the nutrient tank is given below. Similarly, 2 other boxes (Box 2 and 3 ) were connected to the nutrient tank.

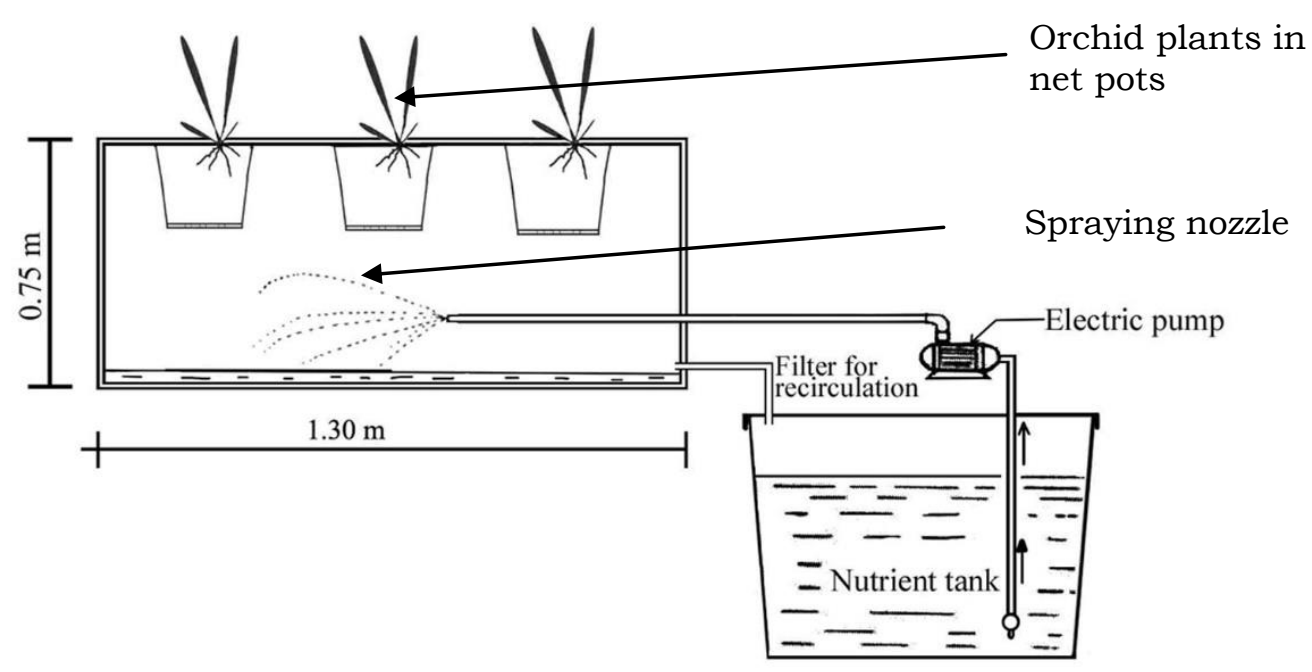

Figure 1. Newly designed (Digramatic view) aeroponics system for cultivating Dendrobium

Each box contained 8 plants and each plant in a specific box (Box 1) was sprayed with $50 \mathrm{mg} / \mathrm{L}$ of sodium silicate for $5 \mathrm{~min}$. Plants in Box 2 with $100 \mathrm{mg} / \mathrm{L}$ of sodium silicate for $5 \mathrm{~min}$ and those in Box 3 were sprayed with water and maintained as the control. Silicon Treatment was given bi-weekly for a period of 12 months. 


\section{Effect of Silicon Supplimentation on Growth Parameters}

Stem length, leaf length and number of leaves per plant were measured in Dendrobium plants treated with silicon as growth parameters and compared with that of the control plants. The stem length was measured from the base of the plant at the soil surface to the apex or tallest point of the plant. Leaf length was measured from leaf base to apex in the third leaf from the apex of each plant. The average value for each of the above parameters was calculated per treatment monthly for several consecutive months.

\section{Effect of Silicon Supplimentation on Flower Quality Traits}

Some flower quality parameters: days for initiation of buds, flowers, number of flowers per spike, flower size (length and diameter), spike length, spike diameter were evaluated for the plants treated with silicon and compared with control plants. Measurements were recorded as stated above.

\section{Levels of Silicon in Silicon Treated Plants}

The amount of silicon absorbed by the leaves and stems was analyzed in plants treated with different levels of sodium silicate and untreated controls (12 plants per each treatment) by analyzing molybdate reactive silica $\left(\mathrm{SiO}_{2}\right)$ by the molibdosilicate method using spectrometry (Clesceri et al., 1998).

$\mathrm{HCl}\left(0.5 \mathrm{~cm}^{3}\right)$ and ammonium molybdate solution $\left(1.0 \mathrm{~cm}^{3}\right)$ were added to $25.0 \mathrm{~cm}^{3}$ of sample solution. The solution was mixed thoroughly and was allowed to stand for 5-10 minutes. Then oxalic acid $\left(1.0 \mathrm{~cm}^{3}\right)$ was added to the same solution and was mixed thoroughly. The absorbance of the solution was measured at $410 \mathrm{~nm}$ after the addition of oxalic acid solution. The Si concentrations of the samples were measured by a plotted calibration curve using standard solutions (silicon) in the range of $4-12 \mathrm{mg} / \mathrm{L}$. The blank (distilled water) was prepared in the same manner and the absorbance was measured.

\section{Disease Resistance of Silicon Treated Plants}

\section{Preharvest Disease Development}

Microscopic observations of diseased leaves showing characteristic 
symptoms of cercospora leaf spot indicated the presence of Pseudocercospora sp. As repeated attempts to cutivate on Potato Dextrose Agar failed, medium enriched with Dendrobium leaf extracts was used for cultivation of the causal agent. This resulted in limited growth of the causal agent, however as colony diameter showed very slow development and as sporulation was not observed, artificial inoculation was not possible.

Hence, natural disease development of leaf spot disease was observed in silicon treated and non treated control plants (Each treatment composed of 12 plants) using a visual scale of diseased leaf area ranging from 1-100\%. Each replicate plant was observed for diseased leaves and the average disease severity per plant was recorded on a weekly basis for a period of three consecutive months.

\section{Histochemical Studies}

The leaf and cuticle thickness in Silicon treated and non-treated control plants, (12 plants each from silicon treated and control) was measured using a stage micrometer and eye piece graticule (Graticules Ltd.) by observing under the low and high power respectively of a light microscope (Micros, Austria).

\section{Analysis of Phenol Compounds}

Total soluble and cell wall bound phenols in plant leaves were analysed using colourimetry (adapted from Ascensao and Dubery, 2003). Leaves showing 25\% natural disease development were selected and assayed inorder to investigate the induced phenolics.

\section{Total phenol levels}

Fresh plant leaves (12 per each treatment) were ground in $80 \%$ Methanol (two grams fresh weight in $10 \mathrm{~mL}$ ) and centrifuged at 3000 rpm (HITACHI-HIMAC) for 10 minutes. The supernatant was filtered through Whatman No.1 filter paper and used for analysis of total soluble phenols while the residue was used for analysis of cell wall bound phenolics. An equal volume of $50 \%$ Folin-Ciocalteu reagent (v/v) was added to $2 \mathrm{~mL}$ of the filtrate, mixed well and left for about 3 minutes. An equal volume of Sodium carbonate $(7.5 \%)$ was added to the above mixture and left to stand for $1 \mathrm{hr}$ at $25{ }^{\circ} \mathrm{C}$. Any resultant particles were filtered off and absorbance was measured at $765 \mathrm{~nm}$ using a UV visible spectrophotometer (Model Labomed UVD 
3000/3200, USA) (Ascensao and Dubery, 2003).

\section{Cell Wall Bound Phenol Levels}

The residue obtained as above was dried at $70{ }^{\circ} \mathrm{C}$ for $24 \mathrm{hrs}$ to obtain the alcohol insoluble residue (AIR). The AIR was suspended in $0.5 \mathrm{M}$ $\mathrm{NaOH}(1 \mathrm{~mL} / 10 \mathrm{mg})$ and left for $1 \mathrm{hr}$ at $96{ }^{\circ} \mathrm{C}$. The supernatant was acidified to $\mathrm{pH} 2$ with $\mathrm{HCl}$ and centrifuged at $3000 \mathrm{rpm}$ for $10 \mathrm{~min}$. The supernatant was extracted into an equal volume of anhydrous diethyl ether. This extraction was repeated two more times, pooled, evaporated to dryness and then resuspended in an equal volume of $80 \%$ methanol and subjected to the Folin assay described above. Absorbance was measured at $765 \mathrm{~nm}$ (Ascensao and Dubery, 2003).

\section{Results and Discussion}

\section{Effect of Silicon Supplementation on Growth Paramenters}

\section{Shoot Length}

All plants either weekly or bi-weekly treated with $100 \mathrm{mg} / \mathrm{L}$ silicon showed a higher shoot length compared to controls. Plants treated with silicon bi-weekly showed the highest value compared to plants treated weekly with silicon or non treated control. The lowest shoot length was observed in non treated control plants. A significant increase in stem height of plants treated with silicon was observed compared with the control plants. However, there was no significant difference between the stem height of plants sprayed with silicon at weekly intervals and bi-weekly.

\section{Leaf Length and Number of Leaves}

Plants treated with silicon either weekly or bi-weekly showed a higher leaf length and number of leaves. The highest was observed in plants treated with silicon at weekly intervals. However, no significant difference in the values of leaf length and number of leaves was observed in treated plants compared with the controls. Silicon treament given at weekly intervals had more impact on increasing the leaf length and number of leaves of Dendrobium Orchids. It has been recorded by Vendrame et al. 2010, that the application of $\mathrm{KSiO}_{3}$ affect overall growth of Phalaenopsis orchid lines and increased fresh weight and dry weight of root shoot and whole plant over the controls. 


\section{Effect of Silicon Supplimentation on Floricultural Quality Traits}

The lowest time was taken for intiation of buds (24 months) and flowers (25 months) in orchid plants treated with silicon at $100 \mathrm{mg} / \mathrm{L}$ weekly intervals. This was significanly different with the plants treated with silicon at bi-weekly intervals and non treated plants with silicon (Table 1).

There were significanly a higher number of flowers (14) in a spike in plants treated with silicon at weekly intervals compared to plants provided with silicon at bi-weekly intervals (flowers in a spike -11) and in non treated controls. The highest length and diameter of flowers (9 $\mathrm{cm}, 7.4 \mathrm{~cm}$ ) was observed in the plants provided with silicon at weekly intervals. The plants recieving silicon bi-weekly, the length and diameter of flowers were $8.2 \mathrm{~cm}, 6.2 \mathrm{~cm}$ or in non treated controls, where these were $8.5 \mathrm{~cm}$ and $6.0 \mathrm{~cm}$.

Similarly, the orchid plants provided with silicon at weekly intervals have shown significantly a higher length of the spikes $(63.20 \mathrm{~cm})$ and diameter $(3.07 \mathrm{~cm})$ compared to the plants provided with silicon biweekly (spike length $-58.70 \mathrm{~cm}$ : diameter $-1.97 \mathrm{~cm}$ ) or non treated with silicon (spike length-59.16 cm: diameter-1.96 cm). It can be concluded that Silicon treatment given at weekly intervals had significantly improved the floricultural quality parameters; early bud and flower intiation, increasing the number of flowers in a spike, diameter, length of flowers, thicker spike thickness and length of Dendrobium flowers compared to the plants treated bi-weekly with silicon $(100 \mathrm{mg} / \mathrm{L})$ or non treated control plants.

Similar observations have been recorded in sunflower and Zinnias by Kamenidou et al., $2008 \& 2009$. The diameter of sunflower was significantly increased and flowers had thick straight stems, and increased plant height when silicon was applied as sodium or potasium silicate to the plants as root drenches or foliar spray. The basal stem diameter of 'Zinnias' was also increased when Potassium silicate was applied as a weekly drench at $100 \mathrm{mg} / \mathrm{L}$.

Savvas et al. 2002 also reported that crop quality of Gerbera improved 
by having thick stems and quality flowers. Similary, Kamenidou et al. 2010 also recorded that Gerbera produced thicker flower pedancles, increased flower diameter, increased height and flowered earlier when treated with sodium silicate. The silicon treated roses also possessed thick stems when treated with silicon (Ehret et al., 2005). All these finding are in agreement with the present study on effects of silicon in improving the floricultural quality traits of Dendrobium orchids.

Preharvest disease caused by Pseudocercospora sp was reduced by over 60\% in Dendrobium plants treated with $100 \mathrm{mg} / \mathrm{L}$ weekly intervals than the plants treated with $100 \mathrm{mg} / \mathrm{L}$ Silicon at bi-weekly intervals or non treated control plants (data not shown).

Table 1. Effects of silicon supplimentation on floricultural quality

\begin{tabular}{|c|c|c|c|c|c|c|c|}
\hline Treatments & $\begin{array}{l}\text { Months } \\
\text { for } \\
\text { anthesis }\end{array}$ & $\begin{array}{l}\text { Month for } \\
\text { Flower } \\
\text { initiation }\end{array}$ & $\begin{array}{c}\text { No of } \\
\text { Flowers }\end{array}$ & $\begin{array}{l}\text { Flower } \\
\text { Length } \\
(\mathrm{cm})\end{array}$ & $\begin{array}{l}\text { Flower } \\
\text { diameter } \\
(\mathrm{cm})\end{array}$ & $\begin{array}{l}\text { Spike } \\
\text { length } \\
(\mathrm{cm})\end{array}$ & $\begin{array}{l}\text { Spike } \\
\text { thickne } \\
\text { ss (cm) }\end{array}$ \\
\hline $\begin{array}{l}\text { Silicon } \\
(100 \\
\text { mg/L) } \\
\text { weekly }\end{array}$ & $24^{a}$ & $25^{a}$ & $14.40^{\mathrm{a}}$ & $9.00^{\mathrm{a}}$ & $7.40^{\mathrm{a}}$ & $63.10^{\mathrm{a}}$ & $3.07^{a}$ \\
\hline $\begin{array}{l}\text { Silicon bi- } \\
\text { weekly }\end{array}$ & $25^{b}$ & $26^{b}$ & $11.20^{\mathrm{b}}$ & $8.20^{\mathrm{b}}$ & $6.20^{b}$ & $58.70^{\mathrm{b}}$ & $1.97^{\mathrm{b}}$ \\
\hline Control & $25.6^{b}$ & $26.6^{b}$ & $11.00^{\mathrm{b}}$ & $8.5^{b}$ & $6.00^{b}$ & $59.16^{b}$ & $1.96^{b}$ \\
\hline
\end{tabular}

Table 2. Effect of different levels of silicon on floricultural quality

\begin{tabular}{lrrrrr}
\hline Treatment & $\begin{array}{c}\text { No of } \\
\text { flowers }\end{array}$ & $\begin{array}{c}\text { Flower } \\
\text { Length } \\
(\mathrm{cm})\end{array}$ & $\begin{array}{c}\text { Flower } \\
\text { Diameter }(\mathrm{cm})\end{array}$ & $\begin{array}{c}\text { Spike length } \\
(\mathrm{cm})\end{array}$ & $\begin{array}{c}\text { Spike } \\
\text { Thickness } \\
(\mathrm{cm})\end{array}$ \\
\hline $50 \mathrm{mg} / \mathrm{L}$ & $5.2^{\mathrm{a}}$ & $8.0^{\mathrm{a}}$ & $7.2^{\mathrm{b}}$ & $23.5^{\mathrm{a}}$ & $1.6^{\mathrm{a}}$ \\
$100 \mathrm{mg} / \mathrm{L}$ & $8.9^{\mathrm{b}}$ & $8.5^{\mathrm{b}}$ & $7.8^{\mathrm{a}}$ & $32.5^{\mathrm{b}}$ & $2.8^{\mathrm{b}}$ \\
Control & $5.5 \mathrm{a}$ & $7.8 \mathrm{a}$ & $7.2 \mathrm{a}$ & $26.6 \mathrm{a}$ & $1.6 \mathrm{a}$ \\
\hline $\begin{array}{l}\text { Different } \\
\text { difference at } \mathrm{P} \leq 0.05\end{array}$ & from the Duncan Multiple Range Test. & denoted & by & supercripts indicate the & significant
\end{tabular}




\section{Levels of Silicon in Silicon Treated Plants}

The amount of silicon absorbed by the leaves and stems was analyzed in plants treated with different levels of sodium silicate and untreated controls, using spectrophotometry. However, an increase of silicon levels of root or shoot or leaves was not observed in silicon treated plants compared to the control. The analysis of silicon of plant material was done to quantify presence of molybdate reactive silica $\left(\mathrm{SiO}_{2}\right)$ and this form of silica may not be the silicon present in the treated plant. Therefore, results obtained from this experiment had no any effect with the silicon treated and control plant.

\section{Effect of Silicon Supplimentation on Orchids Cultivated in Aeroponics System}

Dendrobium cv. Sonia grown in the aeroponics system treated with silicon either $50 \mathrm{mg} / \mathrm{L}$ or $100 \mathrm{mg} / \mathrm{L}$ were shorter than the control. The lowest height was observed in the plants treated with Silicon at 50 $\mathrm{mg} / \mathrm{L}$. Silicon treated plants grown in the aeroponic system showed an average higher number of flowers per spike, greater spike thickness and longer spike length compared to untreated control and plants treated with $100 \mathrm{mg} / \mathrm{L}$ silicon levels.

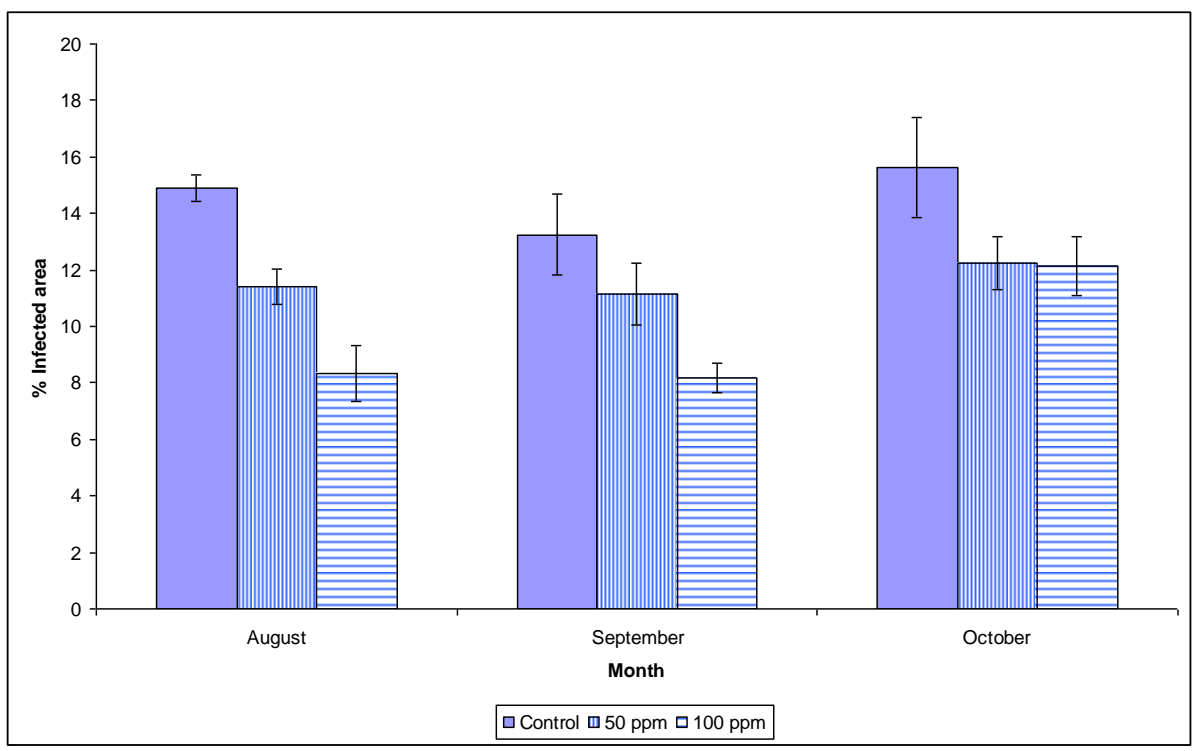

Figure 2. Natural disease development (Leaf spot disease) as shown by \% infected leaf area in silicon treated and control plants. 


\section{Effect of silicon on Disease Development of Leaves}

Natural disese development of leaf spot disease was lower in silicon treated plants as compared to the control throughout the period of evaluation. The lowest disease development was recorded in the 100 $\mathrm{mg} / \mathrm{L}$ silicon treated plants.

Table 3. Effect of Silicon on leaf and cuticle thickness of Dendrobium orchid

\begin{tabular}{|l|l|l|}
\hline Treatment & $\begin{array}{l}\text { Average leaf thicknes: } \\
(\mathrm{mm})\end{array}$ & $\begin{array}{l}\text { Average cuticle thicknes: } \\
(\mu \mathrm{m})\end{array}$ \\
\hline Control & $0.9 \pm 0.05$ & $15.75 \pm 1.20$ \\
\hline $50 \mathrm{mg} / \mathrm{L}$ & $1.12 \pm 0.04$ & $20.6 \pm 1.28$ \\
\hline $100 \mathrm{mg} / \mathrm{L}$ & $1.22 \pm 0.06$ & $23.42 \pm 1.22$ \\
\hline
\end{tabular}

The results indicate that leaf thickness and cuticle thickness are significantly higher in silicon treated plants when compared with the control. The effect of silicon on cuticle and leaf thickness increased with the increase in silicon concentrations.

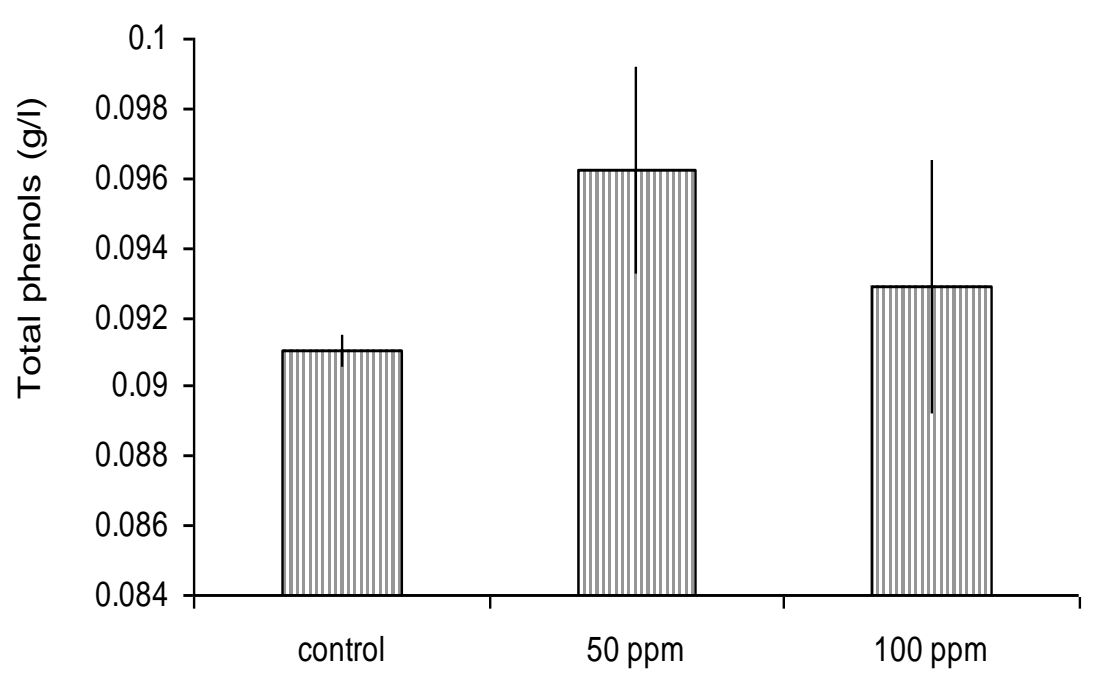

Figure 3. Total soluble phenol content in plants grown in the aeroponic system and treated with varying concentrations of silicon

The total soluble phenol content was higher in both silicon treated at 
$50 \mathrm{mg} / \mathrm{L}$ or at $100 \mathrm{mg} / \mathrm{L}$ silicon treated plants when compared with control plants. Among the treatments, the total soluble phenol content was higher in the $50 \mathrm{mg} / \mathrm{L}$ treatment. Contrastingly, the cell wall bound phenol content was lowest in the $50 \mathrm{mg} / \mathrm{L}$ silicon application $(0.033 \mathrm{~g} / 1 \pm 0.0006)$ while the control and the $100 \mathrm{mg} / \mathrm{L}$ treatment gave higher values of $0.048 \pm 0.005$ and $0.044 \pm 0.007$ respectively.

\section{Conclusions and Recommendations}

All $100 \mathrm{mg} / \mathrm{L}$ silicon treated plants either weekly or bi-weekly showed a higher shoot length, higher leaf length and number of leaves compared to controls. Silicon treatment given at weekly intervals had significantly improved the floricultural quality of Dendrobium flowers compared to the plants treated bi-weekly with silicon $(100 \mathrm{mg} / \mathrm{L})$ or non treated control plants.

Plants grown in aeroponics system and treated with $50 \mathrm{mg} / \mathrm{L}$ silicon weekly showed better floricultural quality traits such as a higher number of flowers per spike and greater spike length, while the 100 $\mathrm{mg} / \mathrm{L}$ treatment showed greater spike thickness and greater flower length and diameter. The overall observation during research was improved floricultural quality traits: a higher number of flowers per spike and higher spike length, higher spike thickness and higher flower length and diameter of Dendrobium.

Natural disease development, leaf spot disease was recorded as, percentage of leaf showing disease symptoms. Natural disease development was significantly lower in plants treated with silicon as compared to the control. This trend was observed consistantly throughout the three months of disease evaluation. Average leaf thickness and cuticle thickness were significantly higher in plants treated with silicon as was the total soluble phenol content. These results indicate that mechanical barriers in the form of cuticle thickness and leaf thckness contribute towards the reduction of disease development. Increased levels of total soluble phenols in leaves of silicon treated plants may be also contributing biochemically towards warding off disease. However, significantly higher levels of cell wall bound phenols were not observed in silicon treated plants in this study. 


\section{Acknowledgement}

Author gratefully acknowledged the Faculty Research Grant (2013), from the Open University of Sri Lanka, and Dr KOLC Karunanayake, Nelum Peris and Sachini Lalanthika for the support given for data collection.

\section{References}

Ascensao, A. R. F. D. C. \& Dubery, I. A. (2003). Soluble and wallbound phenolics and phenolic polymers in Musa acuminata roots exposed to elicitors from Fusarium oxysporum f.sp. cubense. Phytochemistry, 63, 679-686.

http://dx.doi.org/10.1016/S0031-9422(03)00286-3

Belanger, R. R., Benhamou, N. \& Menzies, J. (2003). Cytological Evidence of an Active Role of Silicon in Wheat Resistance tp Powdery Mildew (Blumeria graminis f. sp. tritici). Biochemistry and Cell Biology, 93(4), 402-411.

Blaich, R. \& Grundhöfer, H. (1998) Silicate incrusts induced by powdery mildew in cell walls of different plant species. Journal of Plant Disease Protection, 105, 114-120.

Cherif, M. \& Belanger, R. (1992). Use of potassium silicate ammendments in recirculating nutrient solutions to supress Phythium ultimum on long English cucumber. Plant Disease, 76, 1008-1011.

http://dx.doi.org/10.1094/PD-76-1008

Clesceri, L. S. Greenberg, A. E. \& Eaton, A. D. (1998). Standard methods for the examination of water and wastewater. 20th ed. American Public Health Association, Washington; 1325 p. ISBN 0875532357.

Datnoff, L. E., Snyder, G. H \& Korndorfer, G. H. (2001). Silicon in Agriculture. Amsterdam: Elsevier Science. 
Ehret D. L., Menzies J. C. \& Helmer, T. (2005). Production and quality of green house roses in recirculating nutrient systems. Scientia Horticulture 106, 103-113. http://dx.doi.org/10.1016/j.scienta.2005.03.002

Huang, C., Roberts, P. \& Datnoff, L. (2011). Silicon supresses Fusarium crown rot and root rot of tomato. Journal of Phytopathology, 159 (7-8), 546-554. http://dx.doi.org/10.1111/j.1439-0434.2011.01803.x

Jayawardana, H. A. R. K., Weerahewa, H. L. D. \& Saparamadu, M. D. J. S. (2014)a. Silicon supplimentation by rice hull leachate on the growth, yield, fruit parameters and anthracnose disease resistance of capsicum 'MuriaF1'. International Journal of Multidisciplinary Studies, 1(1), 33-39.

Jayawardena, H. A. R. K., Weerahewa, H. L. D. \& Saparamadu, M. D. J. S. (2014)b. Effect of root or foliar application of soluble silicon on plant growth, fruit quality and anthracnose development of capsicum. Tropical Agricultural Research, $1(26), 74-81$.

Jayawardana, H. A. R. K., Weerahewa H. L. D. and Saparamadu, M. D. J. S. (2016). Rice hull as a silicon source in simplified hydroponic system to enhance anthracnose disease resistance and some growth and fruit parameters of capsicum. International Journal of Recycling of Organic Waste in Agriculture. DOI 10.1007/s40093-015-0112-4

http://dx.doi.org/10.1007/s40093-015-0112-4

Kamenidou, S., Cavins, T. J. \& Marek, S. (2008). Silicon supplements affect floricultural quality traits and elemental nutrient concentrations of greenhouse produced Gerbera. Scientia Horticulture, Vol 123, 390-394. http://dx.doi.org/10.1016/j.scienta.2009.09.008

Kamenidou, S., Cavins, T. J. \& Marek, S. (2009). Evaluation of silicon as a nutritional supplement for greenhouse Zinnia production. Scientia Horticulture, Vol 119, 297. http://dx.doi.org/10.1016/j.scienta.2008.08.012 
Kamenidou, S., Cavins, T. J. \& Marek, S. (2010). Silicon supplements affect floricultural quality traits and elemental nutrient concentrations of greenhouse produced Gerbera. Scientia Horticulture, 123, 390-394.

http://dx.doi.org/10.1016/j.scienta.2009.09.008

Kanto, T., Miyoshi, A., Ogawa, T., Maekawa, K. \& Aino, M. (2006). Suppressive effect of liquid potassium silicate on powdery mildew of strawberry in soil. Journal of General Plant Pathology 72(3): 137-142. http://dx.doi.org/10.1007/s10327-005-0270-8

Kim, S. G., Kim, K. W., Park, E. W. \& Choi, D. (2002). Siliconinduced cell wall fortification of rice leaves; A possible cellular mechanism of enhanced host resistance to Blast. Phytopathology, 92(10), 1095-1103. http:/ /dx.doi.org/ 10.1094/PHYTO.2002.92.10.1095

Kunoh, H. \& Ishizaki, H. (1975). Silicon levels near penetration sites of fungi on wheat, barley, cucumber and morning glory leaves. Physiological Plant Pathology, 5, 283-287. http://dx.doi.org/10.1016/0048-4059(75)90094-6

Ma, J. F. (2004). Role of silicon in enhancing the resistance of plants to biotic and abiotic stresses. Soil Science and Plant Nutrition(50), 11-18.

http://dx.doi.org/10.1080/00380768.2004.10408447

Ma, J. F.,\& Yamaji, N. (2006). Silicon uptake and accumulation in higher plants. Trends in Plant Science, 11(08), 392-397. http://dx.doi.org/10.1016/j.tplants.2006.06.007

Ma, J. F., Nishimura, K. \& Takahashi, E. (1989). Effect of silicon on the growth of rice plant at different growth stages. Soil Science and Plant Nutrition, 35(3), 347-356. http://dx.doi.org/10.1080/00380768.1989.10434768

Menzies, J., Bowen, P. \& Ehret, D. (1992). Foliar application of potassium silicate reduces severity of powdery mildew on 
cucumber, muskmelon and zuccini squash. Journal of the American society for Horticultural Sciences, 6(117), 902-905.

Rodrigues, F. A., Duarte, H. S. S., Rezende, D. C., Filho, J. W., Korndörfer, G. H. \& Zambolim, L. (2010). Foliar spray of potassium silicate on the control of angular leaf spot on beans. Journal of Plant Nutrition 33(14): 2082-2093. http://dx.doi.org/10.1080/01904167.2010.519082

Safari, S., Soleimani, M. J., \& Zafari, D. (2012). Effects of silicon pretreatment on the activities of defense-related enzymes in cucumber inoculated with Fusarium oxysporum. Advances in Environmental Biology, 6(12), 4001-4007.

Samuels, A. L., Glass, A. D. M., Ehret, D. L. \& Menzies, J. G. (1993). The effects of silicon supplementation on cucumber fruit: changes in surface characteristics. Annals of Botany 72(5): 433-440. http://dx.doi.org/10.1006/anbo.1993.1129

Savvas, D., Manos, G., Kotsiras, A. \& Souvaliotis, S (2002). Effects of silicon and nutrient induced salinity on yeild, flower quality and nutrient uptake of Gerbera grown in a closed hydroponic system. Journal of Applied Botany 76, 153-158.

Vendrame, W.A., Palmateer A. J., Pinares, A., Moore K.A. \& Datnoff, L.E. (2010).Silicon Fertilization affects Growth of Hybrid Phalaenopsis Orchid Liners, HortTechnology (http://Horttech.ashspublications.org/content/20/3/603.sho rt)

Weerahewa, D., \& David, D. (2015). Effect of silicon and potassium on tomato anthracnose and on the postharvest quality of tomato fruit (Lycopersicon esculentum Mill.). Journal of National Science Foundation Sri Lanka, 3(43), 273-280. DOI:http://dx.doi.org/10.4038/jnsffr.v4313.7959.

Received: 05-2-2016 Revised: 09-05-2016 Accepted: 11-05-2016 